\title{
Production of foot-and-mouth disease virus SAT2 VP1 protein
}

\author{
Mpho Victoria Mamabolo ${ }^{1,3^{*}}$, Jacques Theron ${ }^{1}$, Francois Maree ${ }^{1,2}$ and Michael Crampton ${ }^{3}$
}

\begin{abstract}
The seven serotypes of foot-and-mouth disease virus (FMDV) differ on the surface exposed regions on the VP1, 2 and 3 proteins. Amongst the three, the VP1 protein has been produced the most for use in serotyping assays for some of the Euro-Asian serotypes. In this study the VP1 protein of the FMDV SAT2/ZIM/7/83 was expressed in Escherichia coli BL21 cells in Luria broth and EnPresso ${ }^{\circledR} \mathrm{B}$ media in shake flasks. Production was further developed and the VP1 protein was produced at $2.15 \mathrm{~g} \mathrm{~L}^{-1}$ in fed-batch fermentations at $2 \mathrm{~L}$ scale. The protein formed insoluble inclusion bodies that were isolated, denatured and refolded. When tested in ELISA, the protein was found to be highly reactive with serum from a SAT2 vaccinated guinea pig, and not reactive to SAT1 and SAT3 antisera. These results open avenues to evaluate recombinantly expressed VP1 proteins for differentiation of the three Southern African Territories serotypes of FMDV that co-occur in Southern and East Africa. In addition, this could mitigate the need for employing virus as reagent, or having to raise reagent antibodies.
\end{abstract}

Keywords: FMDV, VP1, Recombinant, Expression, Fermentation, Diagnostics

\section{Introduction}

Over the past 30 years, there have been efforts to produce the VP1 protein and peptides of the foot-and-mouth disease virus (FMDV) for application in diagnostics or as a vaccine for controlling the economically important and highly infectious foot-and-mouth disease (FMD). The VP1 protein contains most of the virus' neutralization sites, has serotype-determining regions, and is involved in the binding of the virus to host cells (Cheung et al. 1983; Parry et al. 1990; Jackson et al. 2003). For the past 60 years, the disease has been controlled with an inactivated virus vaccine. Traditionally, diagnosis of FMD involve methods that make use of the inactivated virus antigen or, raising of reagent antibodies in laboratory animals. Both vaccine and diagnostic reagents must be produced in high containment facilities to avoid the risk of virus escaping from production facilities to the surrounding environment (Cottam et al. 2008).

\footnotetext{
*Correspondence: MphoMamabolo@ymail.com

${ }^{1}$ Department of Biochemistry, Genetics and Microbiology, University of Pretoria, Pretoria, South Africa

Full list of author information is available at the end of the article
}

The interest in VP1 emanated from studies that demonstrated that the isolated protein could induce a neutralizing response in animals (Laporte et al. 1973; Wang et al. 2015). Structural and functional studies attributed the immunogenicity of VP1 to the presence of 11 T-cell epitopes and three of five virus neutralizing sites (Crowther et al. 1993; Davidson et al. 1995; Grubman and Baxt 2004; Ko et al. 2010; Grazioli et al. 2006; Mahapatra et al. 2012; Rodriguez et al. 1994; Volpina et al. 1999). The VP1 protein also plays a significant role in serotype specificity in the seven FMDV serotypes (Cheung et al. 1983; Jackson et al. 2003; Parry et al. 1990). This led to the search for inexpensive and alternative methods of diagnosing FMD. The VP1 protein has been recombinantly expressed in various hosts including plants ( $\mathrm{Li}$ et al. 2006), yeast (Shi et al. 2006), baculovirus (Li et al. 2008), mammalian cells (Moraes et al. 2002) and bacteria (Jung et al. 2013). Successful challenge experiments where animals were immunized with recombinantly expressed VP1 have been reported. The immune response of these experimental animals and natural hosts produced virus neutralizing antibodies and protection from viral challenge (Grubman et al. 1993; Wigdorovitz et al. 1999a, b).
Springer Open (c) The Author(s) 2020. This article is licensed under a Creative Commons Attribution 4.0 International License, which permits use, sharing, adaptation, distribution and reproduction in any medium or format, as long as you give appropriate credit to the original author(s) and the source, provide a link to the Creative Commons licence, and indicate if changes were made. The images or other third party material in this article are included in the article's Creative Commons licence, unless indicated otherwise in a credit line to the material. If material is not included in the article's Creative Commons licence and your intended use is not permitted by statutory regulation or exceeds the permitted use, you will need to obtain permission directly from the copyright holder. To view a copy of this licence, visit http://creativeco mmons.org/licenses/by/4.0/. 
For application in diagnostics, the C-terminal half of the VP1 protein of the FMDV serotype $\mathrm{O}$ was expressed in Escherichia coli, and antibodies were raised against the protein in guinea pigs. The purified protein and antibodies were then shown to be specific to serotype $\mathrm{O}$ when tested against serotypes A, O, C and Asia-1 in an enzyme-linked immunosorbent assay (ELISA) and latex agglutination test (Suryanarayana et al. 1999). The reliable differentiation of serotype-specific antibodies with recombinant VP1 was demonstrated by Wenger et al. (1999) and by Chen et al. (2016) in an indirect ELISA and Luminex assay respectively. Recombinant VP1 protein was also used as antigen on an immunochromatographic strip for specific rapid detection of FMDV serotype $\mathrm{O}$ (Yang et al. 2010). Although the VP1-encoding gene has been targeted in a PCR assay aimed at detecting SATtype viruses (Bastos 1998), the use of the VP1 protein of the three Southern African Territories (SAT) serotypes of FMDV, viz. SAT1, SAT2 and SAT3, in serology has not been evaluated. Reported here is a production method for the VP1 protein of FMDV SAT2/ZIM/7/83 in shake flask under batch and fed-batch mode. The production process was upscaled to 2-L fermenters. Isolated and refolded recombinant VP1 was evaluated for specificity of the produced protein against SAT1 and SAT3.

\section{Materials and methods}

E. coli strains, plasmids and growth conditions

An E. coli DH10B [F- mcrA $\Delta$ (mrr-hsdRMS-mcrBC)

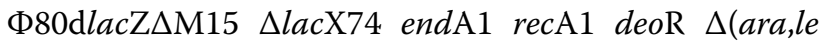
u)7697 araD139 gal $\mathrm{U}$ gal $\mathrm{K}$ nup $\mathrm{G}$ rpsL $\lambda^{-}$] strain used for subcloning was obtained from Invitrogen. E. coli BL21 (DE3) ( $\mathrm{F}^{-}$omp T hsdSB $\left(\mathrm{rB}^{-} \mathrm{mB}^{-}\right.$) gal dcm) used for protein production was obtained from Stratagene. The pBluescript SK (pSK), $\left(\mathrm{Amp}^{\mathrm{R}}\right)$ and pET28a, $\left(\mathrm{Kan}^{\mathrm{R}}\right)$ plasmids were obtained from Stratagene and Novagen, respectively. E. coli cultures were grown in Luria Bertani (LB) medium $\left(5 \mathrm{~g} \mathrm{~L}^{-1} \mathrm{NaCl}, 5 \mathrm{~g} \mathrm{~L}^{-1}\right.$ tryptone, $10 \mathrm{~g} \mathrm{~L}^{-1}$ yeast), $\mathrm{pH} 7$, at $37^{\circ} \mathrm{C}, 200 \mathrm{rpm}$ with $100 \mu \mathrm{g} \mathrm{mL} \mathrm{L}^{-1}$ ampicillin and $50 \mu \mathrm{g} \mathrm{mL}^{-1}$ kanamycin. For protein expression in shake flasks, EnPresso ${ }^{\circledR}$ B (Krause et al. 2010; Ukkonen et al. 2013) (Biosilta) and LB media were evaluated. The former was re-constituted by dissolving EnPresso ${ }^{\circledR}$ B medium tablets in sterile water as per the manufacturer's instructions.

\section{Serum samples}

All anti-FMDV and naïve guinea pig serum samples were obtained from the Agricultural Research Council, Onderstepoort Veterinary Institute. The anti-FMDV serotypes SAT1, 2 and 3 sera were from guinea pigs that were vaccinated with FMDV SAT1/SAR/9/18, SAT2/ZIM/7/83 and SAT3/KNP/10/90, respectively. Naïve serum was from guinea pigs with no history of FMDV infection.

\section{DNA techniques}

Plasmid DNA was isolated with a Zyppy ${ }^{\mathrm{TM}}$ Plasmid Miniprep Kit (Zymo Research) according to the manufacturer's instructions. Restriction enzymes were used as specified by the manufacturers (Epicentre and Thermo Scientific). Plasmid DNA was transformed into E. coli by electroporation (Dower et al. 1988). A 615-base pair (bp) gene encoding the VP1 protein of FMDV SAT2/ZIM/7/83 (GenBank Accession no: DQ009726) was codon-optimized (GenBank Accession no: SAMN11897314) for expression in E. coli and synthesized by GenScript Corp (http://www.genscript.com) (Additional file 1: Fig. S1). The gene was PCR amplified with KAPA HiFi DNA polymerase (KAPA Biosystems) and VP1F (5'-ACTGGA TCCGTTGTTACCACCGACCCGTCT-3'; BamHI site underlined) and VP1R (5'-ACTGCGGCCGCCTGTTTT TCAACACCGATCGG-3' ${ }^{\prime}$ NotI site underlined) primers. Transformants in pSK plasmid (harbouring the amplified gene) were screened by colony PCR with amplification primers (VP1F and VP1R); in a pET28a plasmid vector, they were screened with T7 promoter (5'-TAATACGAC TCACTATAG-3') and VP1R primers. KAPA 2G DNA polymerase (KAPA Biosystems) was used in the screening. The integrity of the cloned $V P 1$ gene was verified by Sanger DNA sequencing, performed by Inqaba Biotechnical Industries.

\section{Construction of pVP1}

The PCR amplified VP1 gene was blunt-end cloned into EcoRV-linearized pSK plasmid DNA with the Fast-Link ${ }^{\mathrm{TM}}$ DNA ligation kit (Epicentre) and transformed into E. coli DH10B to generate pSK-VP1. The pSK-VP1 plasmid was then digested with BamHI and NotI to recover the VPI gene, which was ligated into pET28a digested with the identical restriction enzymes to yield pVP1. The recombinant plasmid was electroporated into E. coli BL21 (DE3) to generate the bacterial strain EC-VP1 that was used in all subsequent experiments. The EC-VP1 bacterial strain was stored as $0.5 \mathrm{~mL}$ glycerol stocks at $-80^{\circ} \mathrm{C}$ until use.

\section{Production of the VP1 protein in shake flasks}

Production of the VP1 protein in shake flasks was evaluated in LB and EnPresso ${ }^{\circledR}$ B (Sigma, USA) media each in triplicate. For both media, the cultures were induced with isopropyl $\beta$-D-1-thiogalactopyranoside (IPTG) to a final concentration of $1 \mathrm{mM}$, following which samples were taken bihourly for 24-h to measure growth at $\mathrm{OD}_{600}$ and protein production. For the latter, samples from the three flasks were pooled for analysis of protein expressed at each time point. 


\section{Expression of VP1 in fed-batch fermentation}

Fermentation of EC-VP1 was carried out in triplicate in 2-L Infors fermenters containing $1.5 \mathrm{~L}$ of medium composed of $2.5 \mathrm{~g} \mathrm{~L}^{-1}$ citric acid, $5 \mathrm{~g} \mathrm{~L}^{-1}$ $\mathrm{NH}_{4} \mathrm{NO}_{3}, 2 \mathrm{~g} \mathrm{~L}^{-1}\left(\mathrm{NH}_{4}\right)_{2} \mathrm{SO}_{4}, 4.5 \mathrm{~g} \mathrm{~L}^{-1} \mathrm{Na}_{2} \mathrm{HPO}_{4} \cdot 2 \mathrm{H}_{2} \mathrm{O}$, $14.6 \mathrm{~g} \mathrm{~L}^{-1} \mathrm{KH}_{2} \mathrm{PO}_{4}, 20 \mathrm{~g} \mathrm{~L}^{-1}$ yeast extract, $\%$ [w/v] glucose, $1 \mathrm{~mL} \mathrm{~L}^{-1}$ antifoam, $0.05 \mathrm{~g} \mathrm{~L}^{-1}$ kanamycin and $5.23 \mathrm{~mL} \mathrm{~L}^{-1}$ trace element solution $\left(0.4 \mathrm{~g} \mathrm{~L}^{-1}\right.$ $\mathrm{CaCl}_{2} \cdot 2 \mathrm{H}_{2} \mathrm{O}, \quad 16.7 \mathrm{~g} \mathrm{~L} \mathrm{~L}^{-1} \quad \mathrm{FeCl}_{3} \cdot 6 \mathrm{H}_{2} \mathrm{O}, 0.15 \mathrm{~g} \mathrm{~L}^{-1}$ $\mathrm{MnCl}_{2} \cdot 4 \mathrm{H}_{2} \mathrm{O}, 0.18 \mathrm{~g} \mathrm{~L}^{-1} \mathrm{ZnSO}_{4} \cdot 7 \mathrm{H}_{2} \mathrm{O}, 0.125 \mathrm{~g} \mathrm{~L}^{-1}$ $\mathrm{CuCl}_{2} \cdot 2 \mathrm{H}_{2} \mathrm{O}, 0.18 \mathrm{~g} \mathrm{~L}^{-1} \mathrm{CoCl} \cdot 6 \mathrm{H}_{2} \mathrm{O}$ and $20.1 \mathrm{~g} \mathrm{~L}^{-1}$ $\mathrm{Na}_{2}$ EDTA). The temperatures were maintained at $37^{\circ} \mathrm{C}$ pre-induction, and reduced to $30{ }^{\circ} \mathrm{C}$ post-induction. The $\mathrm{pH}$ in the vessels was maintained at 7 by addition of $\mathrm{NH}_{4} \mathrm{OH}(30 \% \mathrm{~N})$ or $2 \mathrm{M} \mathrm{H}_{2} \mathrm{SO}_{4}$. The dissolved oxygen (DO) was maintained at or above $40 \%$ saturation by increasing agitation speed in the batch phase. The percentage of dissolved oxygen (DO) was then used as an indirect feedback control during fed-batch process; a decrease of $<40 \%$ in DO triggered the release of the glucose or booster feed. The initial charge of glucose in the fermenters was $2.2 \mathrm{~g}$. The glucose was fed when the initial charge was depleted until induction. After induction, the glucose booster was fed throughout the production phase.

Protein expression was induced $7 \mathrm{~h}$ post inoculation with a final concentration of $1 \mathrm{mM}$ IPTG. A booster (24 $\mathrm{g} \mathrm{L}^{-1}$ yeast extract, $17 \%[\mathrm{w} / \mathrm{w}]$ glucose, $12 \mathrm{~g} \mathrm{~L}^{-1}$ meat free tryptone and $1.5 \mathrm{~g} \mathrm{~L}^{-1} \mathrm{MgSO}_{4}$ ) was fed throughout the protein production phase. Samples were taken from the bioreactors at different time points and analyzed for $\mathrm{OD}_{600}$ and dry cell weight (DCW), whereas protein yields were analyzed at harvest.

\section{Protein extractions and analysis}

To analyze expression of the VP1 protein in E. coli BL21, cells were first lysed. For this, stored cell pellets were resuspended in a Bacterial Protein Extraction Reagent, B-PER ${ }^{\mathrm{TM}}$ (Thermo Scientific), as per the manufacturer's instructions. Pelleted insoluble proteins were solubilized in solubilization buffer $(0.1 \mathrm{M}$ Tris, $\mathrm{pH} 8$, $8 \mathrm{M}$ urea) of equal volume to the starting culture volume and $10 \mu \mathrm{L}$ was analyzed by sodium dodecyl sulfate polyacrylamide gel electrophoresis (SDS-PAGE), as described by Laemmli (1970). The concentration of VP1 was determined by scanning the gel and quantifying the appropriate protein band with BioRad Image lab 4.1 software. Bovine serum albumin (BSA) was included on the gel as a standard. For western blot, a $1 \mu \mathrm{L}$ sample was loaded onto the polyacrylamide gel for analysis.

\section{Inclusion body extraction and refolding}

To extract inclusion bodies, the cell pellet from a $50-\mathrm{mL}$ culture was suspended in B-PER and centrifuged as described above, unless specified otherwise. The pellet was resuspended in DOC buffer $(50 \mathrm{mM}$ Tris, $\mathrm{pH} 8$, $2 \%$ [w/v] sodium deoxycholate, $2 \mathrm{M}$ urea, $5 \mathrm{mM}$ EDTA) and then centrifuged. The pellet was then washed in $50 \mathrm{mM}$ Tris, $\mathrm{pH} 8$, and then solubilized in $5 \mathrm{~mL}$ of $8 \mathrm{M}$ urea and left overnight on a shaking platform. The sample was centrifuged and the supernatant diluted to the original $50 \mathrm{~mL}$ starting culture volume with TNGA buffer (100 mM Tris, pH 8, $100 \mathrm{mM} \mathrm{NaCl}, 1 \%$ glycerol, $1 \mathrm{M} \mathrm{L}$-Arginine), and centrifuged at $18000 \mathrm{~g}$ for $30 \mathrm{~min}$, $4{ }^{\circ} \mathrm{C}$. The supernatant containing refolded protein was loaded on an SDS-polyacrylamide gel for analysis or stored at $-20{ }^{\circ} \mathrm{C}$ until use.

\section{Western blot analysis}

To confirm expression of recombinant VP1, western blot analysis was performed under denaturing conditions according to Gallagher et al. (1997). The immobilized protein was probed with anti-6X His tag antibodies conjugated to horseradish peroxidase (HRP) obtained from Sigma-Aldrich.

\section{Specificity of recombinant VP1}

The specificity of the recombinant VP1 was evaluated by direct ELISA following extraction, isolation and refolding as detailed above. For this, half of a Maxisorp Immunoplate (Nunc) was coated overnight at $4{ }^{\circ} \mathrm{C}$ with $100 \mu \mathrm{L}$ of a $100 \mathrm{mg} \mathrm{L}^{-1}$ VP1 diluted 1:100 in carbonate/bicarbonate buffer $\mathrm{pH}$ 9.6. The other half of the plate was incubated with only coating buffer. All wash steps were repeated three times for a total of four washes with PBS-T buffer $\left(137 \mathrm{mM} \mathrm{NaCl}, 2.7 \mathrm{mM} \mathrm{KCl}, 8 \mathrm{mM} \mathrm{Na} 2 \mathrm{HPO}_{4}, 1.46 \mathrm{mM}\right.$ $\mathrm{KH}_{2} \mathrm{PO}_{4}, 0.05 \%$ Tween-20). After washing, all the wells were incubated with $5 \%$ casein at $37{ }^{\circ} \mathrm{C}$ for $2 \mathrm{~h}$ to block non-specific binding. Sera was added to the wells in octuplicate. The sera was from guinea pigs that were vaccinated with FMDV SAT1/SAR/9/18, SAT2/ZIM/7/83, SAT3/KNP/10/90 and from naïve guinea pigs respectively, diluted 1:1000; $100 \mu \mathrm{L}$ each added to the coated and uncoated wells, respectively, and incubated at $37^{\circ} \mathrm{C}$ for $2 \mathrm{~h}$ with mild agitation. The plate was washed and $50 \mu \mathrm{L}$ of a goat anti-GP IgG F(ab')2 HRP conjugated secondary antibody (Merck), diluted 1:80, was added and the plate incubated at $37{ }^{\circ} \mathrm{C}$ for $2 \mathrm{~h}$. After washing, the ELISA plates were developed by addition of $100 \mu \mathrm{L}$ substrate/chromogen solution $\left[30 \%(\mathrm{w} / \mathrm{v}) \mathrm{H}_{2} \mathrm{O}_{2} / 4 \mathrm{mM}\right.$ TMB in substrate buffer $(0.1 \mathrm{M}$ citric acid 300 monohydrate, $0.1 \mathrm{M}$ tri-potassium citrate; $\mathrm{pH} 4.5$ )] for $10 \mathrm{~min}$. The reaction was stopped with $50 \mu \mathrm{L} 1 \mathrm{M} \mathrm{H}_{2} \mathrm{SO}_{4}$ and 
the absorbance read at $450 \mathrm{~nm}$ using a Labsystems Multiscan Plus photometer. Absorbance readings from the uncoated side were deducted from the coated side to normalize background activity. The results were analyzed by one-way ANOVA.

\section{Results}

\section{VP1 protein expression}

A 615-bp VP1 gene of FMDV SAT2/ZIM/7/83 was amplified (Fig. 1a) and cloned in-frame into the pET28a vector for the expressed protein to contain an $\mathrm{N}$-terminal histidine tag in transformed E. coli (BL21) DE3 cells. A 26-kDa product corresponding to the expected molecular mass of the expressed fusion protein was detected in the insoluble fraction after cell lysis (Fig. 1b) and reacted specifically with anti-histidine antibodies in a western blot (Fig. 1c).

\section{VP1 production in shake flasks}

Production of VP1 was monitored bi-hourly in a time course study for $24 \mathrm{~h}$ post-induction in LB and EnPresso ${ }^{\circledR}$ B media, respectively (Fig. 2). LB medium allows bacteria to grow in a batch mode, whereas the latter medium allows bacteria to grow in a fed-batch mode where the carbon source from the complex medium is released over time.

In LB medium, cultures were induced for protein production at an $\mathrm{OD}_{600}$ of 0.6 (time $=0 \mathrm{~h}$ ). Thereafter, there was exponential growth of EC-VP1 to an $\mathrm{OD}_{600}$ of 6 , followed by a stationary phase. This coincides with protein yields that increased and peaked at $330 \mathrm{mg} \mathrm{L}^{-1}$ at $8 \mathrm{~h}$ post-induction, followed by a decline and thereafter a maintenance of recombinant VP1 concentrations at $\sim 190 \mathrm{mg} \mathrm{L}^{-1}$ until the end of the study.

In EnPresso B medium, cultures were induced for protein expression at an $\mathrm{OD}_{600}$ of 7.4. Recombinant VP1 concentrations were highest at $739 \mathrm{mg} \mathrm{L}^{-1}$ at $8 \mathrm{~h}$ postinduction (at an $\mathrm{OD}_{600}$ of 13), preceded by a higher $\mathrm{OD}_{600}$ of 15 at $6 \mathrm{~h}$ post-induction. In both LB and EnPresso $^{\circledR}$ B media, the VP1 protein was expressed as inclusion bodies. On average, the OD values of EC-VP1 grown in EnPresso ${ }^{\circledR} \mathrm{B}$ medium were at all points during protein production twice or more than EC-VP1 grown in LB. Within $2 \mathrm{~h}$ of induction, protein yields in $\mathrm{LB}$ and EnPresso ${ }^{\circledR}$ B medium were at $122 \mathrm{mg} \mathrm{L}^{-1}$ and $365 \mathrm{mg} \mathrm{L}^{-1}$ respectively. In LB medium, yields peaked $8 \mathrm{~h}$ postinduction at $330 \mathrm{mg} \mathrm{L}^{-1}$, then decreased to $190 \mathrm{mg} \mathrm{L}^{-1}$ and remained at this concentration until the end of the study. In EnPresso ${ }^{\circledR}$ B, yields also peaked $8 \mathrm{~h}$ post-induction at $739 \mathrm{mg} \mathrm{L}^{-1}$ (55\% more than in LB) and by the end of the study the yields had decreased to $374 \mathrm{mg} \mathrm{L}^{-1}$.

Optimal conditions for expression of the recombinant VP1 was in EnPresso ${ }^{\circledR}$ B medium harvested 8 h postinduction with $1 \mathrm{mM}$ IPTG.

\section{VP1 production in fed-batch cultures}

The EC-VP1 bacterial strain was cultured by fed-batch fermentation in $2 \mathrm{~L}$ bioreactors as described under "Materials and methods" section, and the results are presented in Fig. 3 and summarized in Table 1. The

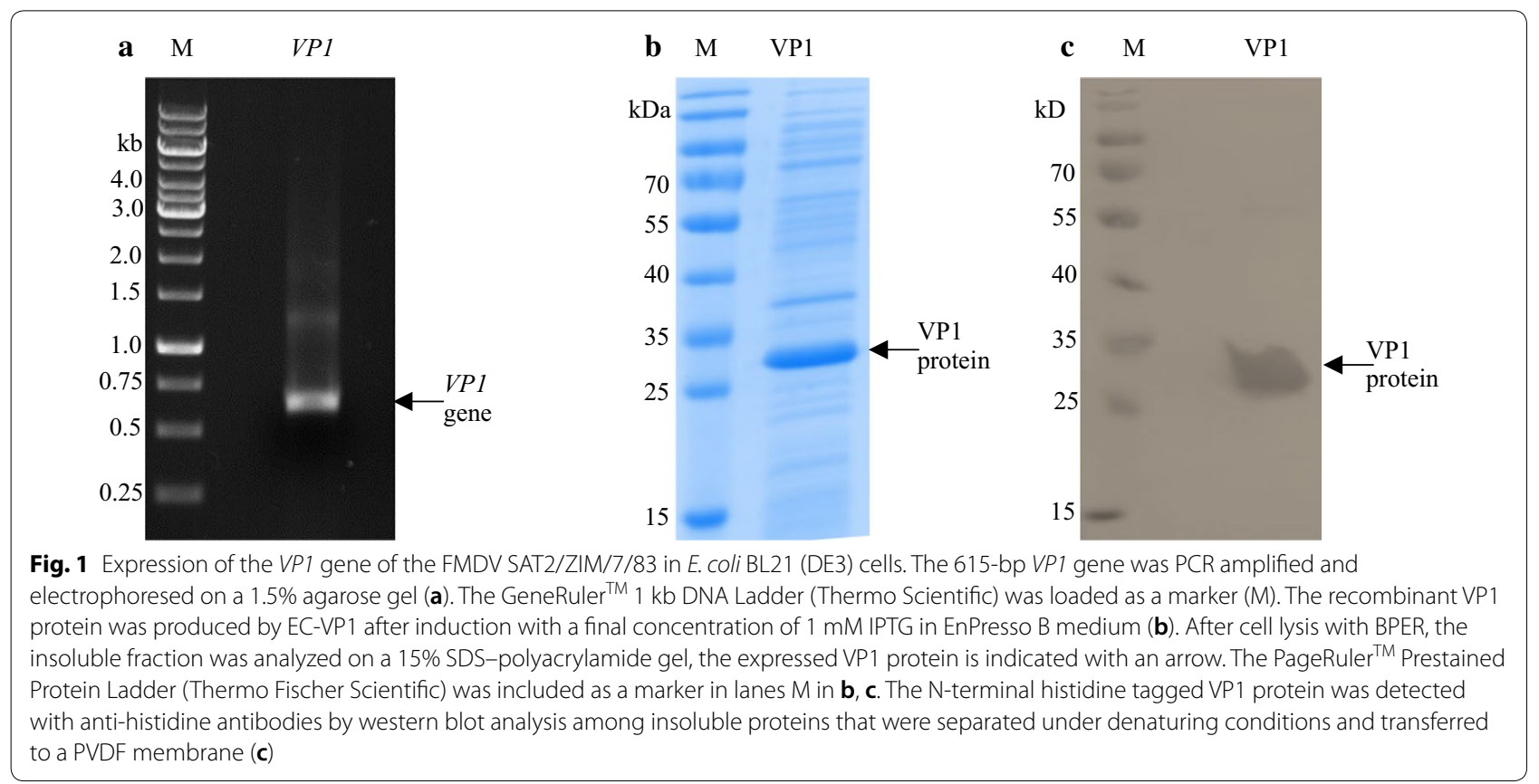



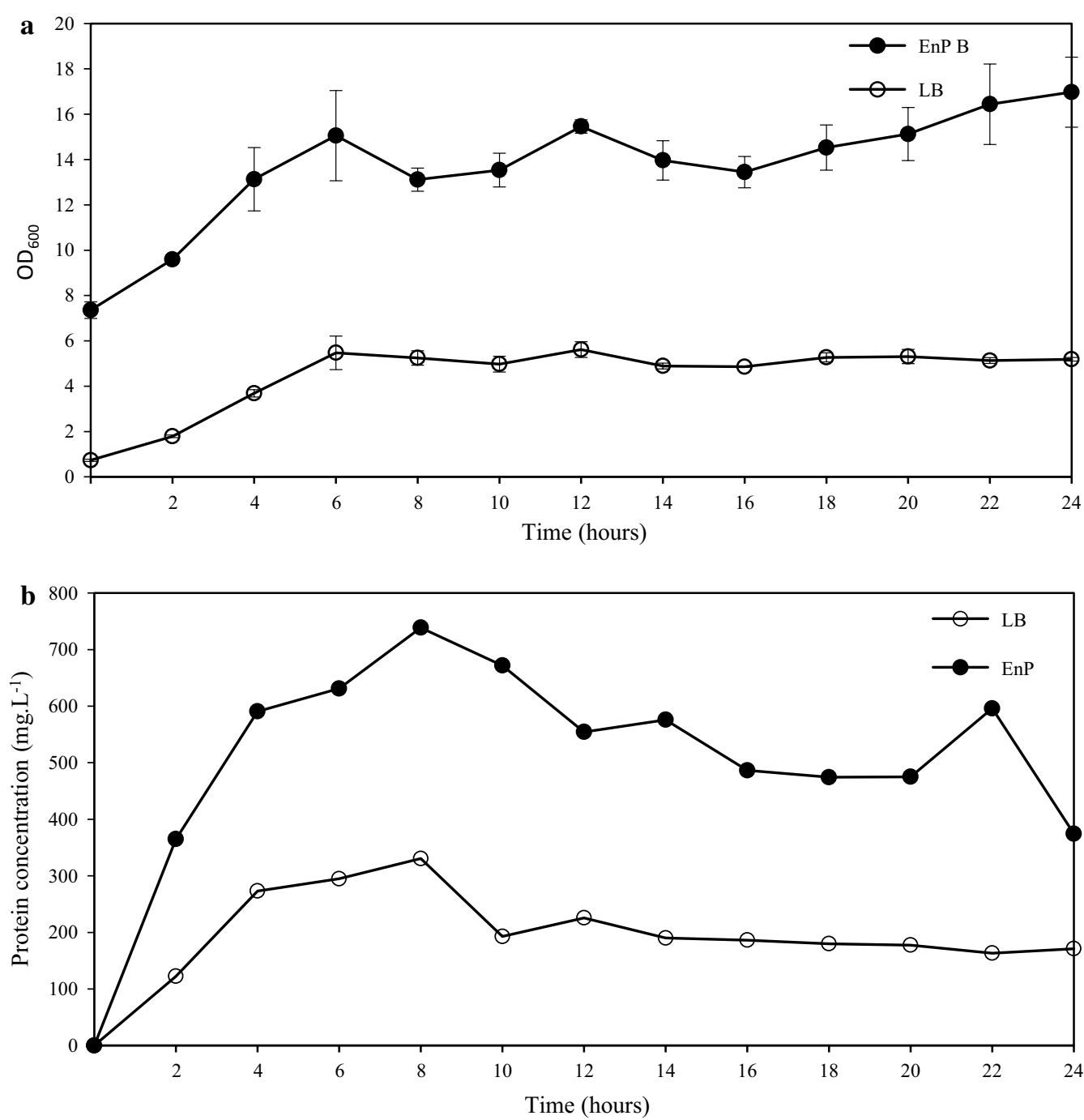

Fig. 2 A graph showing the growth of EC-VP1 in shake flasks measured at $\mathrm{OD}_{600}(\mathbf{a})$ and VP1 protein expressed in EC-VP1 (b) in LB and EnPresso B media measured over $24 \mathrm{~h}$ post-induction. The $\mathrm{OD}_{600}$ was measured bi-hourly in triplicate (error bars indicate the standard deviation) and a pooled sample was analyzed for protein concentrations that were produced over $24 \mathrm{~h}$

initial charge of glucose was consumed in $3 \mathrm{~h}$, followed by a glucose feed. The EC-VP1 cultures were induced for protein production at $7 \mathrm{~h}$ post-inoculation with a final concentration of $1 \mathrm{mM}$ IPTG. Pre-induction, the growth rate of the cultures was $0.432 \mathrm{~h}^{-1}$, with a DCW of $15.4 \mathrm{~g} \mathrm{~L}^{-1}$ and the $\mathrm{OD}_{600}$ was 40 . During the induction phase the growth rate of the cultures reduced to $0.015 \mathrm{~h}^{-1}$, resulting in $2.15 \mathrm{~g} \mathrm{~L}^{-1}$ of product from a biomass of $19.8 \mathrm{~g} \mathrm{~L}^{-1} \mathrm{DCW}\left(\mathrm{OD}_{600}\right.$ of 74 ) at harvest. The specific and volumetric productivities were $0.005 \mathrm{~g} \mathrm{~g}^{-1} \mathrm{~h}^{-1}$ and $0.090 \mathrm{~g} \mathrm{~L}^{-1} \mathrm{~h}^{-1}$, respectively. On average, $47.7 \mathrm{~g} \mathrm{~L}^{-1}$ of glucose was fed during the course of the fermentation.

\section{Specificity}

Following extraction, isolation and refolding, recombinant VP1 protein was $73 \%$ pure (Fig. 4). The specificity of the VP1 was evaluated with sera from each of the SAT serotypes by ELISA. For this, naïve serum $(-$ serum $)$ and immune sera (+serum) of guinea pigs that were vaccinated with FMDV SAT1/SAR/9/81, SAT2/ZIM/7/83 and SAT3/KNP10/90 were reacted with immobilized recombinant VP1 in a direct ELISA, respectively. Chromogen-conjugated anti-guinea pig antibodies reacted with specificity resulting in a high signal with the SAT2 serum, and to a much lesser extent with the SAT1 and SAT3 sera (Fig. 5). This result confirms the antigenicity as well as the specificity of the 


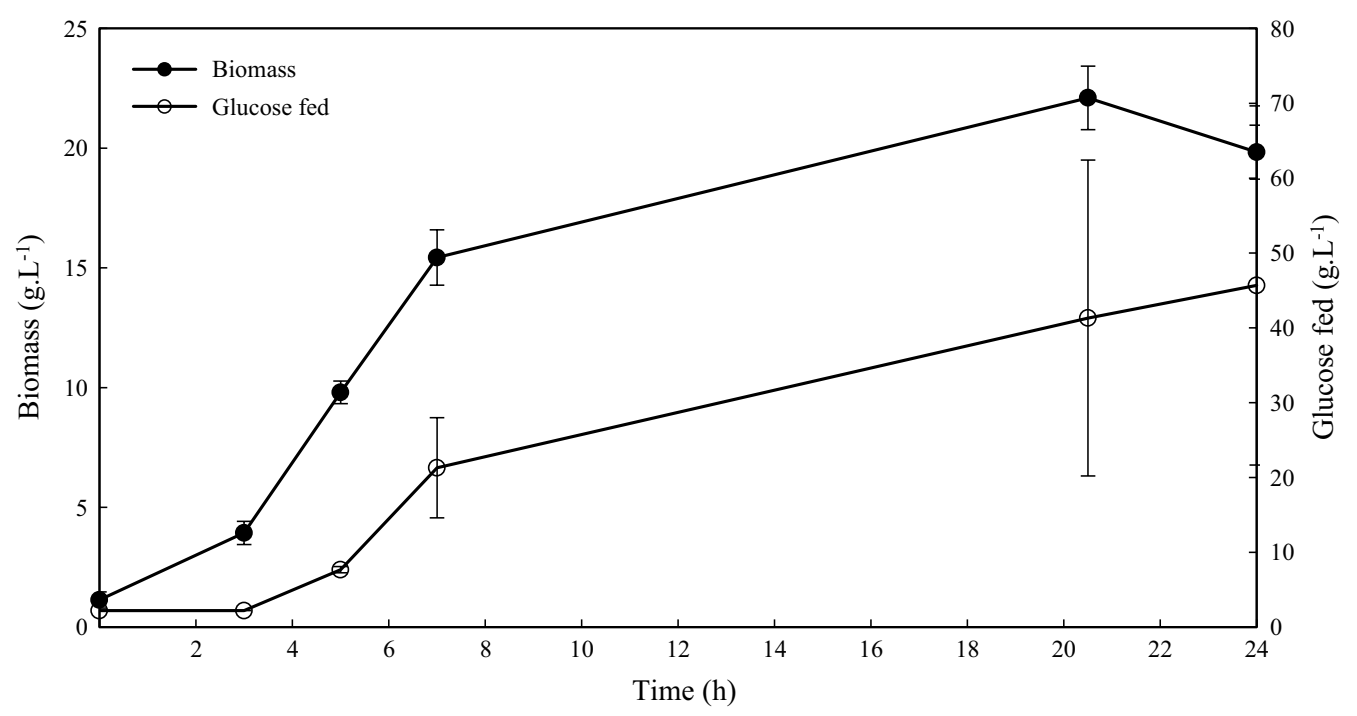

Fig. 3 A graph showing growth of EC-VP1 and glucose fed during the production of VP1 in fed-batch fermentations. Infors fermenters ( $n=3$ ) with $1.5 \mathrm{~L}$ media were each inoculated with $100 \mathrm{~mL}$ of actively growing culture at an $\mathrm{OD}_{600}$ of 0.6 . The cultures were induced for protein production with a final concentration of $1 \mathrm{mM}$ IPTG at $7 \mathrm{~h}$ post-inoculation. Error bars represent the standard deviation

Table 1 A summary of parameters that were measured in the production of recombinant VP1 by fed-batch fermentation

\begin{tabular}{|c|c|c|c|c|c|c|c|c|}
\hline \multicolumn{2}{|c|}{$\begin{array}{l}\text { Dry cell weight } \\
\left(\mathrm{g} \mathrm{L}^{-1}\right)\end{array}$} & \multirow[t]{2}{*}{$\begin{array}{l}\text { Final } O_{600} \\
(600 \mathrm{~nm})\end{array}$} & \multicolumn{2}{|l|}{ Growth rate } & \multirow[t]{2}{*}{$\begin{array}{l}\text { Glucose fed } \\
\left(\mathrm{g} \mathrm{L}^{-1}\right)\end{array}$} & \multirow[t]{2}{*}{$\begin{array}{l}\text { Protein titer } \\
\left(\mathrm{g} \mathrm{L}^{-1}\right)\end{array}$} & \multicolumn{2}{|l|}{ Productivity } \\
\hline At induction & Final & & Pre-induction & Post-induction & & & $\begin{array}{l}\text { Specific } \\
\left(\mathbf{g ~ g}^{-1} h^{-1}\right)\end{array}$ & $\begin{array}{l}\text { Volumetric } \\
\left(\mathrm{g} \mathrm{L}^{-1} \mathrm{~h}^{-1}\right)\end{array}$ \\
\hline 15.4 & 19.8 & 74 & 0.432 & 0.015 & 47.7 & 2.15 & 0.005 & 0.090 \\
\hline
\end{tabular}

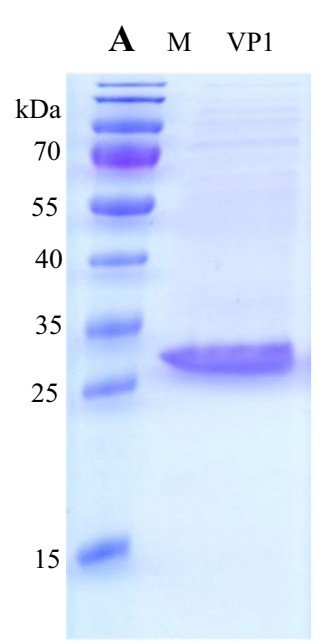

Fig. 4 An image of a 15\% polyacrylamide gel showing recombinant VP1 protein that was extracted, isolated and refolded, resulting in 73\% pure protein. Loaded in lane $\mathrm{M}$ is the PageRuler ${ }^{\mathrm{TM}}$ Prestained Protein Ladder (Thermo Fischer Scientific) recombinantly expressed SAT2 VP1 to serotype-specific antibodies.

\section{Discussion}

Factors that are known to improve the solubility of proteins such as fusing the target protein to negatively charged fusion partners, co-expression of the target protein with chaperone sets, lower growth temperatures and inducer concentrations, using different media, expression of the protein in the E. coli pLysS strain were evaluated for VP1 expression in E. coli. These factors did not influence the solubility of the VP1 protein in this study (data not shown). Although the protein remained insoluble, the EnPresso ${ }^{\circledR}$ B medium resulted in $45 \%$ more product at $8 \mathrm{~h}$ post-induction compared to LB broth (Fig. 2). Other researchers have also reported recombinant protein yield increases when using EnPresso ${ }^{\circledR}$ B compared to LB broth (Ta et al. 2015; Zarschler et al. 2013). The ratio of protein yield per cell was, however, similar for EnPresso ${ }^{\circledR}$ B 


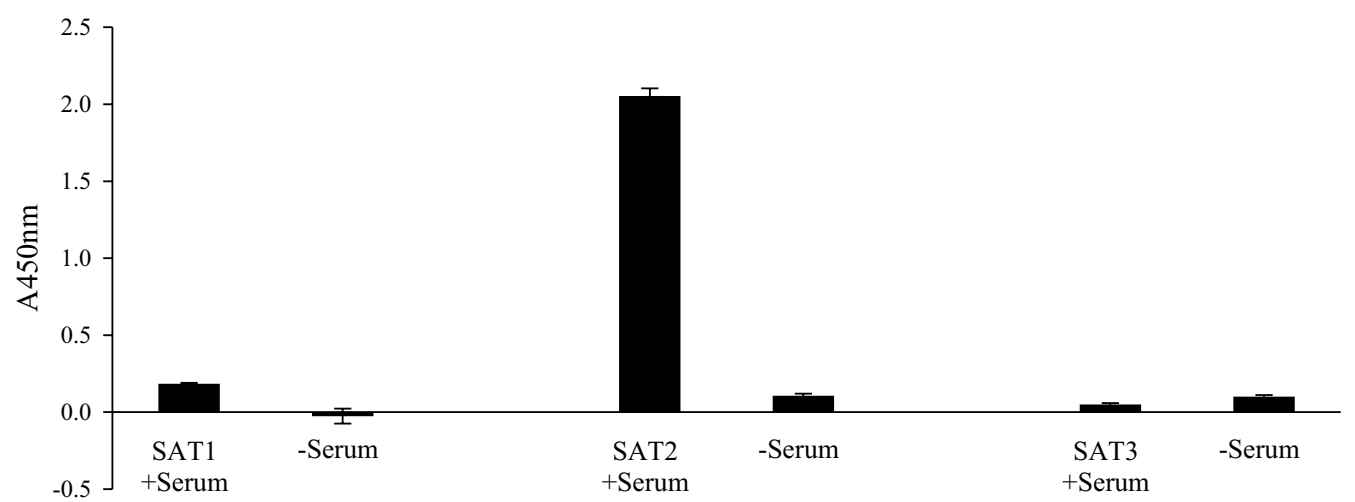

Fig. 5 A graph illustrating the antigenicity and specificity of the recombinant VP1 as measured in a direct ELISA where the expressed VP1 protein was immobilized, then incubated in octuplicate with sera from guinea pigs that were immunized with FMDV SAT1, 2 and 3 viruses, respectively. Serum of naïve guinea pigs were included as controls (error bars represent the standard deviation)

medium and LB broth. This is similar to the observation by Zarschler et al. (2013), where the EnPresso ${ }^{\circledR}$ medium outperformed LB broth in the expression of a single domain antibody 7C12, in E. coli BL21 (DE3) cells. In that study, protein titers of $13 \mathrm{mg} \mathrm{L}^{-1}$ were obtained from a culture of $\mathrm{OD}_{600} 1.4$ grown in LB; compared to titers of $130 \mathrm{mg} \mathrm{L}^{-1}$ from $\mathrm{OD}_{600}$ 13.1. The added advantage of the EnPresso ${ }^{\circledR} \mathrm{B}$ medium is its ability to mimic fed-batch type production at small scale and provide insights into fed-batch fermentation performance. This is unlike LB, which resembles batch-like culture conditions.

In fed-batch fermentations VP1 protein yields were not followed during production, and only measured at harvest. There is a need to monitor recombinant protein production during the production process to understand when to harvest after induction to obtain maximum yield. As such, a comparative analysis of production in EnPresso ${ }^{\circledR}$ B medium and fed-batch fermentations cannot be made in this article. Notwithstanding, in EnPresso ${ }^{\circledR}$ B medium peak production of $739 \mathrm{mg} \mathrm{L}^{-1}$ at an $\mathrm{OD}_{600}$ of 13 was achieved. In comparison, a yield of $2.15 \mathrm{~g} \mathrm{~L}^{-1}$ at an $\mathrm{OD}_{600}$ of 74 in fed-batch fermentations was achieved. Protein production in EnPresso ${ }^{\circledR} \mathrm{B}$ medium was thus superior to fed-batch fermentation, and with simpler relative preparation steps.

During product formation, the growth rate of the EC-VP1 bacterial strain in fed-batch fermentation decreased from 0.432 to 0.015 (97\% decrease). This is attributed to the metabolic load on the recombinant host as most energy and nutrients are diverted to heterologous protein production from cellular growth (Curless et al. 1990; Neubauer et al. 2003). At harvest, the protein yields were $2.15 \mathrm{~g} \mathrm{~L}^{-1}$ from $19.8 \mathrm{~g} \mathrm{~L}^{-1} \mathrm{DCW}$, which is comparable to yields of $3.8 \mathrm{~g} \mathrm{~L}^{-1}$ protein from $63 \mathrm{~g} \mathrm{~L}^{-1}$ of DCW obtained from the fusion of the VP1 epitope (aa
134-173) to GST at an $\mathrm{OD}_{600}$ of 156 in 5-L fermentors (Jung et al. 2013).

Recombinantly expressed VP1 proteins of several serotypes have been shown to be serotype specific. As such, they have been applied in the development of serotyping assays (Suryanarayana et al. 1999). From available literature, the use of serotype O VP1 protein for serotyping has been broadly studied, followed by Asia1. In this study, the specificity of a SAT2 VP1 protein was evaluated against SAT1, SAT2 and SAT3 viruses. The recombinantly expressed VP1 reacted with specificity with serum from a guinea pig that was vaccinated with FMDV SAT2, and negligibly to SAT1 and SAT3. The three SAT types co-occur in the Southern Africa and East Africa, so a diagnostic assay that can unequivocally distinguish them without using virus as reagent or in raising antibodies would be invaluable to the region. Challenges that would have to be overcome for such a test are the high antigenic diversity among SAT viruses. This is not an unsurmountable task as serotype A topotypes, considered to be among the most antigenically diverse in the world, could be detected with VP1 peptides in ELISA (Ko et al. 2010).

To the best of our knowledge this is one of a few reports on the expression of the entire unfused VP1 of the FMDV in E. coli; and the only one on the expression of a SAT2 VP1 protein in E. coli in shake flasks, upscaled to fermentation. Recombinant VP1 and peptides have been evaluated for the serotyping of the Euro-Asian serotypes, but not for the SAT serotypes. The protein was expressed as inclusion bodies that were isolated, denatured and refolded to react with high specificity to viral antigenic sites. This presents prospects for further evaluation of recombinantly expressed VP1 of SAT viruses to be used in serotyping and diagnostic assays. 


\section{Supplementary information}

Supplementary information accompanies this paper at https://doi. org/10.1186/s13568-019-0938-7.

Additional file 1: Fig. S1. Sequence alignment of the FMDV SAT2/ ZIM/7/83 VP1 gene with the E. coli codon optimized gene.

\section{Abbreviations}

aa: amino acid; BSA: bovine serum albumin; DCW: dry cell weight; DO: dissolved oxygen; ELISA: enzyme-linked immunosorbent assay; FMD: footand-mouth disease; FMDV: foot-and-mouth disease virus; HRP: horseradish peroxidase; IPTG: isopropyl $\beta$-D-1-thiogalactopyranoside; LB: Luria-Bertani; OD: optical density; PAGE: polyacrylamide gel electrophoresis; SAT: Southern African Territories; SDS: sodium dodecyl sulfate.

\section{Acknowledgements}

None.

\section{Authors' contributions}

All authors were involved in the study conceptualization, design and analysis of results. MMV was the principal investigator in the study, prepared the manuscript. All authors read and approved the final manuscript.

\section{Funding}

Funding to conduct the study was received from the host institution, Council for Scientific and Industrial Research.

\section{Ethics approval and consent to participate}

Serum that was used in this study was obtained from the diagnostics laboratory at the Agricultural Research Council, Onderstepoort Veterinary Institute. The serum is used for routine diagnostics. No animals were handled in this study, nor was serum prepared for the sole purpose of this study.

\section{Consent for publication}

Not applicable.

\section{Competing interests}

The authors declare that they have no competing interests.

\section{Author details}

${ }^{1}$ Department of Biochemistry, Genetics and Microbiology, University of Pretoria, Pretoria, South Africa. ${ }^{2}$ Agricultural Research Council, Pretoria, South Africa.

${ }^{3}$ Council for Scientific and Industrial Research, Pretoria, South Africa.

Received: 15 May 2019 Accepted: 20 December 2019

Published online: 07 January 2020

\section{References}

Bastos ADS (1998) Detection and characterization of foot-and-mouth disease virus in sub-Saharan Africa. Onderstepoort J Vet Res 65:37-47

Chen TH, Lee F, Lin YL, Pan CH, Shih CN, Tsenh CH, Tsai HJ (2016) Development of a multiplex Luminex assay for detecting swine antibodies to structural and non-structural proteins of foot-and-mouth disease virus in Taiwan. J Microbiol Immunol Infect 49:196-207

Cheung A, DeLamarter J, Weiss S, Kupper H (1983) Comparison of the major antigenic determinants of different serotypes of foot-and-mouth disease virus. J Virol 8(2):451-459

Cottam EM, Wadsworth J, Shaw AE, Rowlands RJ, Goatley L, Maan S (2008) Transmission pathways of foot-and-mouth disease virus in the United Kingdom in 2007. PLoS Pathog 4:e1000050

Crowther JR, Rowe CA, Butcher R (1993) Characterization of monoclonal antibodies against a type SAT 2 foot-and-mouth disease virus. Epidemiol Infect 111(2):391-406

Curless C, Pope J, Tsai L (1990) Effect of pre-induction specific growth rate on recombinant alpha consensus interferon synthesis in Escherichia coli. Biotechnol Prog 6:149-152
Davidson FL, Crowther JR, Nqindi J, Knowles NJ, Thevasagayam SJ, Van Vuuren CJ (1995) Antigenic analysis of SAT 2 serotype foot-and-mouth disease virus isolates from Zimbabwe using monoclonal antibodies. Epidemiol Infect 115(1):193-205

Dower WJ, Miller JF, Ragsdale CW (1988) High efficiency transformation of $E$. coli by high voltage electroporation. Nucleic Acids Res 16:6127

Gallagher S, Winston SE, Fuller SA, Hurrell JGR (1997) Immunoblotting and immunodetection. In: Ausubel FM, Brent R, Kingston RE, Moore DD, Seidman JG, Smith JA, Struhl K (eds) Current protocols in molecular biology. Wiley, New York, pp 10.8.1-10.8.21

Grazioli S, Moretti S, Barbieri I, Crosatti M, Brocchi E (2006) Use of monoclonal antibodies to identify and map new antigenic determinants involved in neutralisation on FMD viruses type SAT 1 and SAT 2. In Report of the Session of the Research Foot and Mouth Disease Group of the Standing Committee of the European Commision of Foot and Mouth Disease. Food and Agriculture Organization, Paphos, Cyprus, pp 287-297. http:// www.fao.org/ag/againfo/commissions/docs/research_group/paphos/ App43.pdf

Grubman MJ, Baxt B (2004) Foot-and-mouth disease. Clin Microbiol Rev 17:465-493

Grubman MJ, Lewis SA, Morgan DO (1993) Protection of swine against footand-mouth disease with viral capsid proteins expressed in heterologous systems. Vaccine 11(8):825-829

Jackson T, King AMQ, Stuart DI, Fry E (2003) Structure and receptor binding. Virus Res 91:33-46

Jung J, Lee YJ, Velmurugan N, Ko Y, Lee H, Jeong K (2013) High-yield production of the VP1 structural protein epitope from serotype $\mathrm{O}$ foot-andmouth disease virus in Escherichia coli. J Ind Microbiol Biotechnol 40:705-713

Ko YJ, Lee HS, Jeoung HY, Heo EJ, Ko HR, Chang BS, Joo HD, Gerelmaa U, Dashzeveg B, Tserendorj S, Sodnomdarjaa R, Park JH, Kweon CH, Choo IS, Paik SG (2010) Use of baculovirus-expressed structural protein for the detection of antibodies to foot-and-mouth disease virus type-A by blocking enzyme-linked immunosorbent assay. Clin Vaccine Immunol 17(1):194-198

Krause M, Ukkonen K, Haataja T, Ruottinen M, Glumoff T, Neubauer A, Neubauer P, Vasala A (2010) A novel fed-batch based cultivation method provides high cell-density and improves yield of soluble recombinant proteins in shaken cultures. Microb Cell Fact 9:11

Laemmli UK (1970) Cleavage of structural proteins during assembly of the head of bacteriophage. Nature 227:680-685

Laporte JM, Grosclaude J, Wantyghem J, Bernard S, Rouze P (1973) Neutralisation en culture cellulaire du pouviour infectieux du virus de la fievre aphteuse par des serums provenant de porcs immunises a l'aide d'une proteine virale purifiee. C R Hebd Acad Sci 276:3399-3402

Li Y, Sun M, Liu J, Yang Z, Zhang Z, Shen G (2006) High expression of foot-andmouth disease virus structural protein VP1 in tobacco chloroplasts. Plant Cell Rep 25:329-333

Li ZY, Yi YZ, Yin XP, Zhang ZF, Liu JX (2008) Expression of foot-and-mouth disease virus capsid proteins in silkworm-baculovirus expression system and its utilization as a subunit vaccine. PLOS ONE 3:1-7

Mahapatra M, Hamblin P, Paton DJ (2012) Foot-and-mouth disease virus epitope dominance in the antibody response of vaccinated animals. $J$ Gen Virol 93:488-493

Moraes MP, Mayr GA, Mason PW, Grubman MJ (2002) Early protection against homologous challenge after a single dose of replicon defective human adenovirus type 5 expressing capsid proteins of foot-and-mouth disease virus (FMDV) strain A24. Vaccine 20:1631-1639

Neubauer P, Lin HY, Mathiszik B (2003) Metabolic load of recombinant protein production: inhibition of cellular capacities for glucose uptake and respiration after induction of a heterologous gene in Escherichia coli. Biotechnol Bioeng 83(1):53-64. https://doi.org/10.1002/bit.10645

Parry N, Fox G, Rowlands D, Brown F, Fry E, Acharya R, Logan D, Stuart D (1990) Structural and serological evidence for novel mechanism of antigenic variation in foot-and-mouth disease virus. Nature 347:569-572

Rodriguez A, Saiz JC, Novella IS, Andreu D, Sobrino F (1994) Antigenic specificity of porcine $T$ cell response against foot-and-mouth disease virus structural proteins: identification of T helper epitopes in VP1. Virology 205:24-33 
Shi XJ, Wang B, Zhang C, Wang M (2006) Expressions of bovine IFN-gamma and foot-and-mouth disease VP1 antigen in P. pastoris and their effects on mouse immune response to FMD antigens. Vaccine 2:82-89

Suryanarayana VVS, Viswanathan S, Ratish G, Bist P, Prabhudas K, Gajendragad MR, Natarajan C (1999) E. coli expressed proteins as diagnostic reagents for typing of foot-and-mouth disease virus. Arch Virol 144:1701-1712 Ta DT, Redeker ES, Billen B, Reekmans G, Sikulu J, Noben JP, Guedens W, Adriaensens P (2015) An efficient protocol towards site-specifically clickable nanobodies in high yield: cytoplasmic expression in Escherichia coli combined with intein-mediated protein ligation. Protein Eng Des Sel 28(10):351-363

Ukkonen K, Mayer S, Vasala A, Neubauer P (2013) Use of slow growth feeding as supporting carbon source in lactose autoinduction medium improves the robustness of protein expression at different aeration conditions. Protein Expr Purif 91:147-154

Volpina OM, Surovoy AY, Zhmak MN, Kuprianova MA, Koroev DO, Chepurkin AV, Toloknov AS, Ivanov VT (1999) A peptide construct containing B-cell and $T$-cell epitopes from the foot-and-mouth disease viral $V_{1}$ protein induces efficient antiviral protection. Vaccine 17:577-584

Wang M, Zhou P, Lv J, Zhang Z, Wang Y, Zhang Y (2015) Protection against foot-and-mouth disease virus in guinea pigs via oral administration of recombinant Lactobacillus plantarum expressing VP1. PLOS ONE 10(12):e0143750

Wenger M, Tratschin J, Hofmann M (1999) Indirect ELISA using recombinant VP1 capsid protein for the serodifferentiation of foot-and-mouth disease virus infected animals. J Virol 5:454-455
Wigdorovitz A, Carillo C, Dus Santos MJ, Trono K, Peralta A, Gomez MC, Rios RD, Franzone PM, Sadir AM, Escribano JM, Borca MV (1999a) Induction of a protective antibody response to foot and mouth disease virus in mice following oral or parenteral immunization with alfalfa transgenic plants expressing the viral structural protein VP1. Virology 255:347-353

Wigdorovitz A, Filgueira DMP, Robertson N, Carillo C, Sadir AM, Morris TJ, Borca MV (1999b) Protection of mice against challenge with foot and mouth disease virus (FMDV) by immunization with foliar extracts from plants infected with recombinant tobacco mosaic virus expressing the FMDV structural protein VP1. Virology 264:85-91

Yang S, Yang J, Zhang G, Wang X, Qiao S, Zhao D, Zhi Y, Li X, Xing G, Luo J, Fan J, Bao D (2010) Development of an immunochromatographic strip for the detection of antibodies against foot-and-mouth disease virus serotype $\mathrm{O}$. J Virol Methods 165:139-144

Zarschler K, Witecy S, Kapplusch F, Foerster C, Stephan H (2013) High-yield production of functional soluble single-domain antibodies in the cytoplasm of Escherichia coli. Microb Cell Fact 12:97

\section{Publisher's Note}

Springer Nature remains neutral with regard to jurisdictional claims in published maps and institutional affiliations.

\section{Submit your manuscript to a SpringerOpen ${ }^{\circ}$ journal and benefit from:}

- Convenient online submission

- Rigorous peer review

- Open access: articles freely available online

- High visibility within the field

- Retaining the copyright to your article

Submit your next manuscript at $\boldsymbol{\nabla}$ springeropen.com 